emerald International Journal of Sustainability in Higher Education
PUBLISHING

\title{
Enhancing Student Engagement in Business Sustainability Through Games
}

\begin{tabular}{|r|l|}
\hline Journal: & International Journal of Sustainability in Higher Education \\
\hline Manuscript ID & IJSHE-05-2017-0075.R2 \\
\hline Manuscript Type: & Research Paper \\
\hline Keywords: & $\begin{array}{l}\text { Student Engagement, Game-based Learning, Business Sustainability, } \\
\text { Education for Sustainability, EfS, Games }\end{array}$ \\
\hline \multicolumn{2}{|l}{} \\
\hline
\end{tabular}

SCHOLARONE $^{\text {M }}$
Manuscripts 


\title{
Enhancing Student Engagement in Business Sustainability Through Games
}

Dr Kay Emblen-Perry

University of Worcester, Business School, Worcester, UK

City Campus, Castle Street, Worcester, WR1 3AS. Tel: 01905855253

Email: k.emblenperry@worc.ac.uk

Paper Submitted 30 May 2017

Paper Revised 02 November 2017

\begin{abstract}
Purpose: This practice-focused study explores the value students place on the Sustainable Strategies Game which seeks to improve student engagement in business sustainability through enhanced game-based learning. This game provides an alternative collaborative learning environment to the traditional instructivist approach in order to enrich Education for Sustainability learning experiences and enhance student engagement.
\end{abstract}

Design/Methodology/Approach: Students' reflections on their game-based learning experiences and suggestions for game development were collected through a short qualitative survey. Results are explored through three frameworks, the Multifaceted Student Value Model, the Dimensions of Engagement Framework and the UK Higher Education Authority Framework for Engagement Through Partnership.

Findings: Research findings suggest the Sustainable Strategies Game provides gamebased learning within Education for Sustainability that delivers 'edutainment' within an active, collaborative and experiential learning environment that the students value. It is also able to challenge thinking and emotionally engage students with the fundamentals of business sustainability. Reflection-on-action and the students' role as co-researchers in game development allow students to become active participants in their learning as well as knowledge producers and evaluators. These outcomes deliver the UK Higher Education Authority's core facets of student engagement through partnership.

Research limitations/implications: This practice-focused study presents the self-reported results of a one-time, small study which does not offer generalised, independently validated 
responses. However, the findings may be of interest to educators considering the adoption of game-based learning and those seeking new learning cultures for EfS.

Practical Implications: Game-based learning and teaching approaches can achieve a learner-centred active, collaborative learning environment that enhances student engagement with business sustainability.

Originality/Value: Experiences gained from this study should assist others in the implementation of game-based learning to engage students in business sustainability.

Key words: Student Engagement, Game-based Learning, Business Sustainability, Education for Sustainability, EfS, Games.

Paper Type: Research Paper

\section{Introduction}

Learners' preferences for experiential, collaborative learning activities are now rapidly evolving and the need to develop students' literacy skills in sustainability to prepare them for the workplace are reshaping the practice of Education for Sustainability (EfS) in the Higher Education (HE) environment (HEFCE, 2013; Higher Education Academy, 2015). These trends are shifting traditional instructivist approaches to learning and teaching towards participatory user interactions (Conole and Alevizou, 2010).

To address these demands the author utilises a role-based game to offer participatory approaches to EfS learning and teaching for Level 5 and Level 6 students; the Sustainable Strategies Game (SSG). This is one of a variety of active, collaborative approaches to business sustainability learning and teaching that are implemented by the author. SSG underpins the ethos of sustainability that is taught within the business curriculum: environmental and social impact mitigation, collaboration, resilience etc. Frequently these require ethical and moral sensitivities to be included. Embedded within the game is the expectation that students will challenge their own, as well as organisational 
sustainability values.

SSG is designed to encourage experiential learning and engage students in business decision-making within the complexity of sustainability. This requires them to consider economic growth, prudent use of natural resources, protection of the environment and influence on the local communities. The game seeks to develop students' understanding of the potential impacts that businesses can have on the environment and society and encourages their investigation of alternative strategic responses. It also supports students' engagement with the softer skills of business management such as negotiation, collaboration and influencing in the safe environment of a lecture room and group activity.

Leach (2016) suggests student engagement is one of the most important issues currently facing the HE community. There is considerable research evidence to suggest playing games can improve students' learning and engagement (Cooper et al. 2010; Fabricatore and Lopez, 2012; McGrath and Bayerlein, 2013; Nagle et al. 2014; Cheong Filippou and Cheong, 2014) hence SSG has been introduced. It seeks to meet Net'geners preferences for experiential and collaborative learning (Oblinger and Oblinger, 2005) and deliver student-centred learning for insight rather than learning for technique (Beech and MacIntosh, 2012). This can enhance students' experience and engagement through peer-topeer learning, collaboration, negotiation and problem solving. Problem solving may involve cognitive investment, emotional commitment and active participation for engagement and deeper learning (Chapman, 2012). Tilbury and Wortman (2008) consider that games promote new ways of learning and thinking, which is considered vital within EFS (HEFCE, 2013).

SSG aims to engender the individual and collective sense of responsibility that Burgess (2006) and Ellison and Wu (2008) consider able to motivate learning for good practice, which is a fundamental requirement of EfS. Its ability to develop self-perceived competence may be a key motivator for engagement (Fazey and Fazey, 2001). 
The game offers a different environment to the more familiar instructivist approaches frequently used within business management, such as tutor led, slide-based lectures. It provides an alternative, interactive, experiential perspective to learning and teaching in which students may engage in deeper learning as they are actively involved in a learning task rather than being passive recipients of information (Cross, 1987). Active participation in the game seeks to engage students through education, entertainment, challenging their thinking, and generating an emotional response. These are used as indicators of engagement in this research.

The research presented here is taken from the first cycle of action research into improving students' engagement with EfS in the business context. Students' experiences of playing SSG are explored and assessed in relation to the game's ability to engage students in EfS. This level of engagement is evaluated in two dimensions: firstly, through students' perceptions of the game as an educational and entertaining learning experience that is able to challenge thinking and generate an emotional response and secondly, through students' suggestions for future developments of the game that are an indicator of their cognitive investment and engagement.

This paper provides an evidence-based case study that contributes to the debate over pedagogical approaches to EfS and offers an insight into experiences of students, which may be of use to others in the sustainability community considering similar game based learning and teaching opportunities.

\section{Sustainability in business education}

For the last two decades, sustainability has been gaining an increasing focus in Higher Education (Figuero and Raufflet, 2015) and the potential for universities to address global sustainability issues through learning, teaching and research is now well recognised 


\section{The game and game-based learning and teaching context}

Incorporating games as a learning and teaching approach is gaining prominence within business EfS to achieve the new learning culture advocated by Rieckmann (2011) and Molthan-Hill (2014). Serious games such as Fishbanks (Meadows, Sterman and King, 2017), the Orange Trading Game (Traidcraft, 2017)), SIM Sweatshop (Norridge, 2017) and the Green and Great (Centre for Systems Solutions, 2017) present interactive opportunities to explore multiple facets of sustainability within the work environment. SSG adds to this portfolio of learning and teaching tools and offers the opportunity for students and educators to explore sustainable decision making within the manufacturing sector.

\section{The wider context of game based learning and teaching}

The value of game-based learning as a type of game play with defined learning outcomes (Shaffer, Halverson, Squire and Gee, 2005) is widely accepted within literature to generate positive effects on learning (Gee, 2007; Davis and Sumara, 2006; Annetta et al., 2009; Katsaliaki and Mustafee, 2015). Some studies, however, temper this view and suggest that 
whilst games have value within teaching and learning, their effectiveness for enhancing student achievement is influenced by the game's design and specific instructional purpose (Hays, 2005; Gee, 2007). Young et al., (2012) argue the positive effect on student achievement may not be achieved if games are presented as short activities that lack relevance for players. These conflicting views on the impact of games may be determined by the theoretical approach taken; a cognitive perspective suggests games are motivating but outcomes are likely to be influenced by the game-play processes whereas a socio-cultural perspective suggests games will only provide positive outcomes if they are embedded in relevant in-game information and interactions (Plass, Homer and Kinzer, 2015).

Although more research is required to establish long-term outcomes of games on student achievement (Young et al., 2012) and deeper learning, initial evidence exists to suggest games are able to engage and motivate students who no longer find traditional approaches engaging (Wrzesien and Raya, 2010; Cheong, Filippou and Cheong, 2014; Nagle et al., 2014). Cooper et al., (2010) considers this is because they harness collective problem-solving abilities of players. Consequently, games provide a valuable learning environment for EfS as they engage players in cognitively demanding tasks that require problem-solving and decision-making skills (Fabricatore and Lopez, 2012). Tsai, Yu and Hsaio, (2011), however, caution that games' ability to motivate learning may be disrupted by the distraction of game-playing and players' lack of desire to learn. Incorporation of games into a variety of teaching methods, so that they are not the sole instructional strategy, may therefore be more effective for ongoing engagement (Tsai, Yu and Hsaio, 2011, Young et al., 2012),

Dieleman and Huisingh (2006), however, consider games are valuable for EfS as they are able to shift players' ideas through increasing their awareness of personal values and environmental behaviours. Kafai, (2006) supports this, considering the quality of engagement in a game a significant indicator of its ability to energise behaviour change. Consequently, this research explores the ability of SSG to challenge students' thinking. 
Features within games can generate adaptive responses by challenging behaviours if they are specific problem solving activities (Schell, 2008). Gee (2007) suggests contextualisation of these features within the game will generate experiential learning that can motivate players to engage in rethinking game-playing strategies, whilst Miller and Page (2007) consider unexpected events introduced to a game's environment encourage students to understand and adapt their behaviours. Such unexpected events may require adaptive responses to cope with added complexity introduced (Bloom, 2010). Thus this research seeks to use the potential interventions identified by students as indicators of cognitive investment, emotional response and active participation, to explore student engagement in SSG.

Core traits within games offer opportunities to change behaviours and develop learning (Fabricatore and Lopez, 2012). These include uncertainty, i.e. the inability to fully predict or control processes related to outcomes, and non-linearity, i.e. the interaction among games elements that can generate different outcomes. Lizzio and Wilson (2008) consider game-problems valuable as they provide opportunities to change behaviours, develop ideas and encourage collaboration in the safe environment of a game.

Game-problems may generate the individual and collective sense of responsibility within players that is able to drive learning for good practice (Ellison and Wu, 2008). The author considers this learning for good practice needs to address the learning expectations of students and their future employers as well as to engage students in sustainable futures and advocacy for sustainability within the workplace. SSG attempts to engage students with EfS and challenge their thinking to develop learning for insight (Beech and Maclntosh, 2012) rather than providing the frequently accepted instructivist environment in which students employ just-in-time learning for technique that Zepke and Leach (2010) consider as a route to gain a passport to employment. Annetta et al., (2009) suggests a sense of responsibility comes from implementing game-features that reward or challenge behaviours to achieve compromise between stimulating engagement and maintaining focus on learning. 


\section{The Sustainable Strategies Game}

SSG is a role-based game in which groups of students (self-selected) act as the management teams of manufacturing businesses sited around a body of fresh water. Several hundred thousand people live in villages and small towns in close proximity to the production plants and also rely on this common water resource. Each company depends on the local communities to provide a workforce.

The game is played within a three-hour taught session with the author acting as facilitator. Playing SSG takes around two hours which allows time for an initial briefing and post-game debriefing. The initial briefing incorporates the theory of the Tragedy of the Commons; individuals' rational behaviour maximises personal gain from exploiting natural resources but causes widespread harm to the community as those involved exist in an environment of finite resources (Hardin, 1968). This concept is presented in the context of SSG to highlight the challenge players will face in operating manufacturing processes that depend on obtaining the critical production input of clean, fresh water from the common water source. The post-game debrief encourages players to revisit the challenges presented by SSG and reflect on behaviours, strategic choices and sustainability values.

At the start of the game the groups are given a game playing brief which provides cues to learning along with details of their business and its' social, natural and economic environment. They are also advised the winning team will receive a prize but are not told what the prize is. The winning team is the company with the highest bank balance at the end of the game.

Throughout the game, the groups are tasked with addressing a number of problems including how to operate a plant profitably whilst considering the prudent use of the shared natural resource and impact on the local environment and communities. As each plant operates it utilises water from the common water source and releases pollutants back into it. The successful operation of each business, and therefore profitability, relies on the quality of 
the water available. There is no environmental regulation in place to control emissions or water abstraction. This is deliberately excluded to encourage players to consider their personal values, which are vital for sustainability advocacy, rather than constraining their thinking with regulatory parameters.

SSG is played over a series of rounds in which the players must make strategic operational decisions: to limit their pollution through reducing discharges to the water body or continue to pollute by conducting business as usual. There is no set number of rounds; SSG is generally played over $18-20$ rounds although the rounds can be tailored to the time available.

At the end of each round, the facilitator collects and records each groups' strategic decision and presents the class position, i.e. the number of teams choosing to conduct business as usual and therefore exacerbate pollution and the number choosing to limit pollution. All choices are anonymous to ensure students are able to test out strategies and maintain their income (gains and losses) privately and without fear of embarrassment. Each group maintains a record of their decisions and the payoff received

The payoff from the players' decisions in each round is an income that is related to the quality of the water. Water quality is determined by the combined strategic choices made by all manufacturing plants; the more groups that choose to pollute the water the more the water quality decreases. The key to maintaining water quality is to maximise the number of groups limiting their pollution. If the water quality declines the manufacturing plants' production processes are negatively impacted; costs increase so that income falls.

The players' decision making in each round requires groups to consider their potential income, risks and rewards of their chosen strategy and the choices of all other groups. These decisions are taken within the game environment of other groups' behaviours and the players' personal perspectives on sustainability. 
After eight rounds, additional game-features and interventions are introduced to challenge and potentially provoke changes to students' game-play strategies. From round 9 onwards the management teams can negotiate and collaborate prior to making their strategic decisions. This is incorporated to encourage students to engage in collaborative decision making, which is vital to achieve sustainable futures. In addition, players are given the choice to pay to prosecute the most polluting company (a one off payment). As with the general success rate of environmental prosecution, teams have a 1-in-3 chance of being fined which is determined on the role of a dice. If successfully prosecuted the guilty party is financially penalised.

A series of game-features that introduce the community's voice into the game are also introduced after the initial rounds. At the start of round 10 the facilitator announces that the Mayor of a local town has made a plea for manufacturers to improve their protection of the water as there are plans to develop community leisure facilities at the lake. If groups continue to pollute the water a social media campaign is then raised against the most polluting company (the group that has voted to continue polluting through conducting business as usual most often) to encourage students to explore the challenges of profit maximisation versus environmental protection and encourage consideration of businesses' impacts on the local communities. The game provides a structure for learning how businesses may deal with this complex environment for decision making.

\section{Factors influencing students' gaming experience}

Frymier and Schulman (1995) suggest students should recognise the relevance and value in the learning to engage with it. Pelozi and Shang (2011) define this value for consumers as their perception of the return from interactive and relativistic experiences. As students are consumers of educational output (Vanderstraeten, 2004) they can be considered to act as customers showing evolving preferences for interactive and relativistic learning and teaching experiences, i.e. collaborative, interactive, experiential learning activities. Students respond 
to the learning and teaching experience, in a similar way to customers reacting to a service or product, that is they make a judgement whether to engage or not based on the perceived expectation of the value the experience offers. Students' experience from game-based learning and teaching may therefore depend on their level of education, their familiarity with edutainment, and their experiential exposure to the issues within the game.

Interacting in-game processes within the game may influence the students' gaming experience (Iten and Petko, 2016). For SSG these include the introduction to the game, the game process itself, players' confidence in their understanding of the game and the postgame debriefing. When introduced to the game students are provided with both written and verbal game-play instructions to ensure different learning styles are addressed as recommended by Kolb (2014). At the end of the game students are debriefed. This uses a constructivist approach to learning that allows the construction of knowledge through reflection on game-play experience recommended by Krause and Coates (2008). This debriefing may also help students engage in a community of learning, enabling them to share and explore group-generated strategies and provide and receive peer feedback and reflection that promotes student engagement (Kuh, Kinzie and Buckley, 2006). Additionally, the individual and group behaviours and expectations that are generated within the game may contribute to players' experiences, for example the potential status-rewards from winning, team members' willingness to collaborate or cooperate and team members' personal attitudes towards business responsibilities. The opportunity to collaborate after round eight of SSG may present challenges to groups' and individual students' behaviours and inspire development of alternative and/or combined operating strategies.

During each round of SSG the groups appraise the encountered and perceived risks and rewards within the game, which are able to affect players' gaming experiences and in turn encourage behaviour changes (Wang and Sun, 2011). In-game rewards include the maximisation of financial returns which are generated by groups' strategic choices and decisions to spend capital to increase future returns, investment for technological 
improvement or investment to potentially penalise others. Game risks encountered by each group are affected by external factors such as other groups' strategic choices, which influence the income received, and the players' assessment of the likelihood of being fined for being the most polluting company.

\section{Research methodologies}

This article presents the findings from the initial cycle of action research to investigate the value SSG has for generating student engagement through experiential game based learning and teaching within business EfS. It fits into a larger longitudinal study exploring the impact of innovative, active learning approaches to EfS. Action research offers a systematic approach to identifying innovations (Braun and Clark, 2006) which Riding, Fowell and Levy (1995) consider an opportunity to improve learning and teaching practice. It combines evidence from a survey conducted with nineteen Level 6 and eleven Level 5 students after they played a single game and reflections from the author. Students had a range of experience of business sustainability learning. Some Level 6 students had taken a business sustainability module at Level 5 (but had not played SSG previously); no Level 5 students had previously studied business sustainability within WBS or played the game. This small study presents the initial findings as an example of game-based learning and teaching that offers a learner centred, collaborative learning environment that may engage students with business sustainability.

The author employed a short qualitative survey to explore student engagement that allowed students to reflect on the quality of their learning experience. This survey asked three questions: 1) What was your experience of playing the Sustainable Strategies Game? 2) If you were to be involved in revising the game what changes would you make? 3) What features could be included within the game to further challenge you to change your company's business strategy? The questions were deliberately open ended to encourage 
students to reflect on both what was learned and the learning process. This can inspire learners to develop attitudes through reflection on values and behaviours encountered to generate deeper learning (Stubbs, 2011) and encourage them to process external information which leads to understanding and productive thinking, not just the reproduction of information (Mayer, 1996).

The survey collected evidence to explore two indicators of engagement: firstly, students' testimonies as to SSG's ability to provide both learning and entertainment and secondly students' recommendations for enhancements to SSG as an indicator of their engagement. These two evidence bases will establish the potential for SSG to educate, entertain, challenge thinking and elicit an emotional response, which demonstrate students' cognitive investment, emotional commitment and active participation; the three factors that Chapman and Dunkerley (2012) suggest generate engagement.

The questionnaire was distributed at the end of the game prior to the debriefing session to ensure individuals' experiences were not biased by group discussion. It emphasised reflection-on-action (Schön, 1987) and asked students to mentally revisit their personal feelings and events to gain insights into their intellectual and emotional engagement with the game and EfS. All students were given participant numbers and are used within the analysis of findings below. Codes P1 to P19 identify Level 6 students and P20 to P31 Level 5 students. The author's reflections on game play interactions and outcomes and student behaviours are also included.

This qualitative, reflective approach also encouraged students to engage deeply with sustainability concepts, which are frequently moral and ethical in nature, and think about their learning. Barnett (2007) suggests that such complex open-ended ideas, perspectives, values, beliefs and interpretations, which require students to engage intellectually and emotionally, will generate engagement and deep learning.

Two deductive methodologies were employed to analyse the research findings and 
further investigate students' experiences of playing SSG: Thematic Analysis and Multifaceted Student Value Modelling. Thematic Analysis produces qualitative analyses of responses to questions related to people's experiences, views and perceptions (Burns, 2005; Braun and Clark, 2006), a key focus of this research. Initially students' values of the game for learning and teaching were used to explore levels of engagement with SSG. This was undertaken through a Thematic Analysis of students' survey responses using core words related to learning (e.g. 'educational' 'insightful' 'informative') and entertainment (e.g. 'fun', 'enjoy') to establish students learning experiences. Findings from the Thematic Analysis were collated both qualitatively and quantitatively and where appropriate, findings were related to the students' level of study.

Survey responses were also explored through the Multifaceted Student Value Model. This adapted version of the Multifaceted Customer Value Model (Pelozi and Shang, 2011) examined the potential that SSG has for creating value for students from their game-playing experience of learning thus enhancing engagement. This value is interactive and relativistic; interactive as it is created when the student and game come together and relativistic as each player's perception is influenced by external factors relative to the learning environment. The potential for engagement was assessed along two value orientation dimensions (vertical axis) and two spatial orientation dimensions (horizontal axis). This provided four potential value streams that can define the type of value for engagement offered: educational value (Quadrant 1), entertainment value (Quadrant 2), expression value (Quadrant 3) and performance value (Quadrant 4).

To assess the strength of student engagement the Dimensions of Engagement Framework (Emblen-Perry, 2017), based on Chapman and Dunkerley's three generators of engagement, was used. Players feedback that indicated their reaction to, or feeling towards the game, was categorised as 'cognitive investment', 'emotional commitment' or 'active participation' which Chapman and Dunkerley (2012) suggest generate engagement. Students' responses were located on the framework according to the degree of engagement 


\section{Results}

\section{Students' experience of playing}

Participants' responses to the survey indicate the majority of students consider SSG both educational and entertaining; $96 \%$ of students confirm that playing SSG engaged them in learning and $77 \%$ confirmed that they found the game entertaining. For example:

I learned companies that have concern over resources, environment and pollution usually lose out in terms of profit (P6, Level 6)

It was a good way of understanding the point of sustainable thinking (P26, Level 5) 
The game was enjoyable (P4, Level 6)

I had a fun experience playing the game, trying to suss out what other groups

responses would be in order to choose our strategies (P11, Level 6)

Over two thirds of Level 6 students and $62 \%$ of Level 5 students use core words for both education and entertainment in their survey responses. For example:

Eye-opener, enjoyable, educational (P1, Level 6)

I really enjoyed it and found it informative (P15, Level 6)

I learned new things by enjoying a team game (P30, Level 6)

Fun interactive experience which enabled me to think about how sustainability would impact businesses in real life situations (P22, Level 5)

Charsky (2010) considers that if education and entertainment can be seamlessly combined within learning and teaching the resulting experience is 'edutainment'. The findings of this research suggest that students consider SSG offers 'edutainment' that has engaged them. For example, one student considers SSG to be,

An excellent game that kept me fully engaged (P31, Level 5)

The survey responses indicate students develop a high level of self-perceived game competence when playing SSG, which Fazey and Fazey (2001) suggest is a key motivator for engagement. For example:

It was fun and a different experience to the lecture. I enjoyed working with my team to make conscious sustainable decisions (P24, Level 5)

It was good working together and coming up with a strategy (P11, Level 6)

The author notes that SSG engenders students' competitive nature and it appears 
that success with the competitive elements of the game (particularly if their competitors were penalised by their actions) added to their self-perceived competence and enjoyment of playing.

When explored in more detail the research findings indicate both Level 6 and Level 5 students recognise SSG as a valuable source of learning whilst being entertained. $100 \%$ of Level 6 students and $92 \%$ of Level 5 students indicate that they engaged in learning; $74 \%$ and $83 \%$ respectively reported being entertained. This suggests that more Level 6 students recognise the learning delivered through SSG than Level 5 students.

However, more Level 5 students identified their enjoyment, suggesting that this cohort were more engaged in the entertainment of game playing. This may be due to differences in students' academic experience, exposure to business strategy making and/or experience of game-based learning. The author notes that 5 weeks after playing the game (which included the Easter break) Level 5 students were still talking about their enjoyment of SSG and what they would do differently if they were to play again e.g. collaborating earlier in the game, adopting different business strategies etc.; Level 6 students asked to play more games and some even brought their own games into the taught sessions.

The research findings show that over two thirds of students at both Level 6 and Level 5 felt their thinking was challenged by playing SSG. Students' responses suggest that through this game $68 \%$ of Level 6 and $66 \%$ of Level 5 students engaged cognitively with game based learning and teaching. For example:

Positive and insightful [experience] about other people's behaviour and business (P13, Level 6)

[It] made me think about the needs and wants of the game in comparison to individual vs. collective rationale (P12, Level 6)

It also opened my mind how difficult it is to make a change in the right direction if you 
are alone (P21, Level 5)

[It] made me understand that it is so complex to act sustainable for a company thinking about profit and environment at the same time (P26, Level 5)

[It] taught me the complexity of making such sustainability decisions within a real life study (P28, Level 5)

Although the majority of students' responses suggest that playing SSG had challenged their thinking, fewer appear to have developed an emotional response to the game. However, whilst this impact is lower, SSG has still managed to emotionally engage almost $50 \%$ of the players. Examples of evidence for this include:

It made you think about the importance of sustainability, and whether the prize was more important than being sustainable (P4, Level 6)

We made the most profit out of all the businesses - so from a business perspective we were successful. However, from someone who is concerned about the environment then the 'limit pollution' action should have been considered more often (P6, Level 6)

It was difficult to make the 'right decision' based on what we thought other groups would do (P10, Level 6)

Helps boost understanding on what the actual effect on businesses, locals etc. of pollution and regularly how business can get away with doing their own thing (P18, Level 6)

The author recognises that tension between a willingness to 'do the right thing' at the expense of sacrificing potential maximum short-term returns developed between and within groups. Research findings suggest some students recognise this and highlight the conflict between their desire to win and knowing their group is not behaving sustainably. This aspect 
of the game playing experience will be explored further in future research to maximise the opportunities it presents to enhance engagement in sustainability learning.

To further understand the level of students' engagement engendered by SSG, players were asked to suggest opportunities that could be incorporated to enhance their experience of playing the game. This helps to embed the processes taking place within the game and makes them more relevant to the audience, which Wolfe and Byrne (1975) and Armier, Shepherd and Skrabut (2016) suggest further develops engagement. Analysis of survey responses indicates that $94 \%$ of students made at least one suggestion for a potential development of SSG, with $45 \%$ suggesting two or more opportunities for improvement.

The largest number of proposed developments involved additional game-features to challenge players' behaviours and rethink strategic choices: These additional features included:

Droughts or other natural disasters (P5, Level 6)

Tragic circumstances to illicit different responses (P11, Level 6)

A prize for the most sustainable company as well as for the most profitable will make teams decide what is most important to them (P24, Level 5)

Students considered additional game-features that increased penalties for the most polluting companies, or improving rewards for groups contributing the least pollution would increase the challenge of the game and provide more incentive to negotiate collaborative strategies. Students suggestions included:

Make sure that all businesses are punished for continued use of business as usual (P2, Level 6)

More sanctions for polluters/rewards for sustainable choices (L30, Level 5) 
Add bad publicity and reduce revenue able to be made by polluting companies ( $P 14$, Level 6)

Increase the chance to get fined to $50 \%$ (P31, Level 5)

Include random mechanisms to trigger changes to strategy played e.g. visit by Environment Agency and deductions for most polluting company id last three rounds (P27, Level 5).

These suggestions were accompanied by preferences for clear naming and shaming of the groups demonstrating unsustainable practices. The author notes students' enjoyment of the competitive elements of the game, highlighted by their game-play behaviour, may indicate this suggestion has been made to improve their chance of beating other teams rather than challenging behaviours. Further research will explore which of the proposed game-play additions could appropriately enhance the purpose of SSG.

Six students suggested the game instructions could be simplified as they appear to over complicate the rules. One recommended utilising a video to explain the game requirements and suggested it could be watched independently before the in-class session to speed up, and potentially enhance, players' engagement in the games' purpose and rules (P2, Level 6).

Only three students suggested SSG could be digitised and played online. They suggested digitisation would make the game more anonymous and speed up the game. This was framed by students P18 (Level 6) and P5 (Level 6) as an opportunity to play more rounds of SSG rather than play for a shorter period of time. One student reflected:

I completed simulations games whilst studying in Germany. These games were computerised and we did not physically see the decisions of other groups. This might be a good thing to do with this game. (P8 Level, 6) 
The number of improvement suggestions made and the detail of the development provided emphasises students' engagement with the learning outcomes, purpose and rules of the game. They also highlight that players engaged sufficiently with the game-play interactions and in-game problems that needed to be overcome to be able to recognise potential improvements.

\section{Multifaceted Student Value Model for student engagement}

The findings of the Multifaceted Student Value Model (Figure 1) suggest that SSG offers considerable levels of value to both individual players and groups (self-oriented and other oriented values).

\begin{tabular}{|c|c|c|}
\hline & Intrinsic value & Extrinsic value \\
\hline $\begin{array}{l}\text { Self-oriented } \\
\text { value }\end{array}$ & $\begin{array}{l}\text { Quadrant 1: Efficiency } \\
\text { (e.g. SSG engaged students by } \\
\text { offering value as an efficient } \\
\text { educational tool) } \\
\text { Evidence for this value is included in } \\
\text { the student responses from: } \\
\text { P1, P2, P3, P4, P5, P6, P7, P8, P9, } \\
\text { P10, P13, P15, P16, P18, P19, P20, } \\
\text { P21, P22, P23, P24, P26, P28, P29, } \\
\text { P30, P31 }\end{array}$ & $\begin{array}{l}\text { Quadrant 3: Status } \\
\text { (e.g. SSG engaged students by } \\
\text { offering value through allowing } \\
\text { demonstration concern for wellbeing } \\
\text { of others/nature) } \\
\text { Evidence for this value is included in } \\
\text { the student responses from: } \\
\text { P2, P3, P5, P10, P11, P12, P14, } \\
\text { P16, P18, P19, P26, P28, P31 }\end{array}$ \\
\hline $\begin{array}{c}\text { Other } \\
\text { oriented value }\end{array}$ & $\begin{array}{l}\text { Quadrant 2: Joy } \\
\text { (e.g. SSG engaged students by } \\
\text { offering value as entertainment and } \\
\text { in-game gain) } \\
\text { Evidence for this value is included in } \\
\text { the student responses from: } \\
\text { P1, P2, P3, P4, P7, P8, P10, P11, } \\
\text { P12, P14, P15, P16, P17, P19, P21, } \\
\text { P22, P24, P25, P26, P27, P28, P30, } \\
\text { P31 }\end{array}$ & $\begin{array}{l}\text { Quadrant 4: Ethics } \\
\text { (e.g. SSG engaged students by } \\
\text { offering value as opportunity to act } \\
\text { ethically/sustainably) } \\
\text { Evidence for this value is included in } \\
\text { the student responses from: } \\
\text { P4, P5, P6, P8, P10, P17, P18, P19, } \\
\text { P21, P22, P23, P26 }\end{array}$ \\
\hline
\end{tabular}

Figure 1: The Multifaceted Value Model assessing SSG's value for student engagement [adapted from Multifaceted Customer Value Model, Pelozi and Shang (2011)] 
The student responses within Quadrant 1 (Educational Value) highlight the value SSG offers for learning and the likelihood of engaging individual students with the learning offered.

Similarly, the responses in Quadrant 2 (Entertainment value) show the students' perceptions of value of SSG for engagement through entertainment and the game's ability to engage groups of players. Quadrant 3 (Expression value) and Quadrant 4 (Performance value) suggest a lower, but still relevant number of students, perceived SSG valuable for showing concern for their wellbeing of others and the environment and an opportunity to act sustainably. The largest number of students' reflections on their game playing experiences are positioned in Quadrants 1 or 2 of the Multifaceted Student Value Model with many of the same students appearing within both quadrants. This further reinforces players' perceptions of the value of SSG for 'edutainment'.

The students' feedback located in Quadrant 1 suggests both Level 5 and Level 6 students consider that SSG has provided them with sustainability literacy skills. However, Level 6 students appear more likely to recognise the value the game offers individuals and groups to demonstrate their sustainability thinking and the game's extrinsic opportunities for learning. This may be due to their experience and level of education. The Multifaceted Student Value Model's findings indicate that there is an opportunity to further develop the value offering of the game in advocacy for sustainability, demonstrating concern and acting sustainably, which will be addressed in future research.

\section{Discussion of research findings}

The research findings suggest that SSG provides an opportunity to engage students within learning and teaching for EfS and develop sustainability literacy skills through game-based edutainment and participatory interaction. These findings can be further assessed against the Dimensions of Engagement Framework (Emblen-Perry, 2017) and the HEA Framework for Engagement Through Partnership (Higher Education Academy 2016) to the evaluate the 
extent of this engagement.

Mapping evidence from the students' survey responses against the Dimensions of Engagement Framework (Emblen-Perry, 2017) shown in Figure 2 suggests students have engaged strongly with the game to cognitively invest in their learning and have actively participated. Although fewer comments indicate an emotional response to the sustainability concepts in the game, those students commenting on this demonstrate high levels of engagement.

\begin{tabular}{|c|c|c|c|}
\hline & Weak engagement & Medium engagement & Strong engagement \\
\hline $\begin{array}{l}\text { Cognitive } \\
\text { investment }\end{array}$ & & $\begin{array}{l}\text { It was an interesting } \\
\text { game } \\
\text { It was valuable to see the } \\
\text { results }\end{array}$ & $\begin{array}{l}\text { Eye-opener... } \\
\text { Insightful... } \\
\text { It was valuable... } \\
\text { Fun and challenging... } \\
\text { Helpful and challenging... } \\
\text { Helps to boost } \\
\text { understanding } \\
\text { Made you think... } \\
\text { It opened my mind... } \\
\text { Very challenging game... } \\
\text { Taught me... } \\
\text { The game was highly } \\
\text { educating... } \\
\text { I learned new things... } \\
\text { I learned a lot.... } \\
\text { You understand how... } \\
\text { Educational... }\end{array}$ \\
\hline $\begin{array}{l}\text { Emotional } \\
\text { commit- } \\
\text { ment }\end{array}$ & & & $\begin{array}{l}\text { Good game even though } \\
\text { we lost } \\
\text { I enjoyed working with my } \\
\text { team to make conscious } \\
\text { sustainable decisions } \\
\text { Excellent game that kept } \\
\text { me entertained and fully } \\
\text { engaged } \\
\text { It is a shame destroying } \\
\text { the environment is a } \\
\text { profitable activity }\end{array}$ \\
\hline Active & & A different experience to & Great experience... \\
\hline
\end{tabular}




\begin{tabular}{|c|c|c|}
\hline $\begin{array}{l}\text { particip- } \\
\text { ation }\end{array}$ & the lecture & $\begin{array}{l}\text { Using our tit-for-tat } \\
\text { strategy.... } \\
\text { It was good working } \\
\text { together... } \\
\text { Fun, interactive } \\
\text { experience... } \\
\text { Engaging experience in } \\
\text { comparison to normal } \\
\text { lectures as it required me } \\
\text { to be more involved } \\
\text { Played in class as a } \\
\text { group } \\
\text { I really enjoyed playing } \\
\text { the game and I would be } \\
\text { interested in playing more } \\
\text { games like this } \\
\text { The game was easy to } \\
\text { understand } \\
\text { Enjoyable... } \\
\text { An engaging } \\
\text { experience... } \\
\text { Challenging... } \\
\text { Different to normal lecture } \\
\text { and more } \\
\text { understanding... }\end{array}$ \\
\hline
\end{tabular}

Figure 2: Students' experiences of playing SSG mapped against the Dimensions of Engagement Framework

Relating the research findings to the HEA Framework for Engagement through Partnership (Higher Education Academy, 2016) allows SSG to be evaluated against established factors proven to deliver deep engagement (Figure 3). Figure 3 shows that being involved in playing, reflecting on the game playing experience and considering opportunities to improve the game, SSG has provided learning and teaching outcomes that allow both students and staff to reflect on, inspire and enhance practice for learning, which is the objective of the Framework for Engagement Through Partnership. 
Students as knowledge producers. Achieved through:

$\checkmark$ Game playing

$\checkmark$ Game development

$\checkmark$ Reflection-on-Action

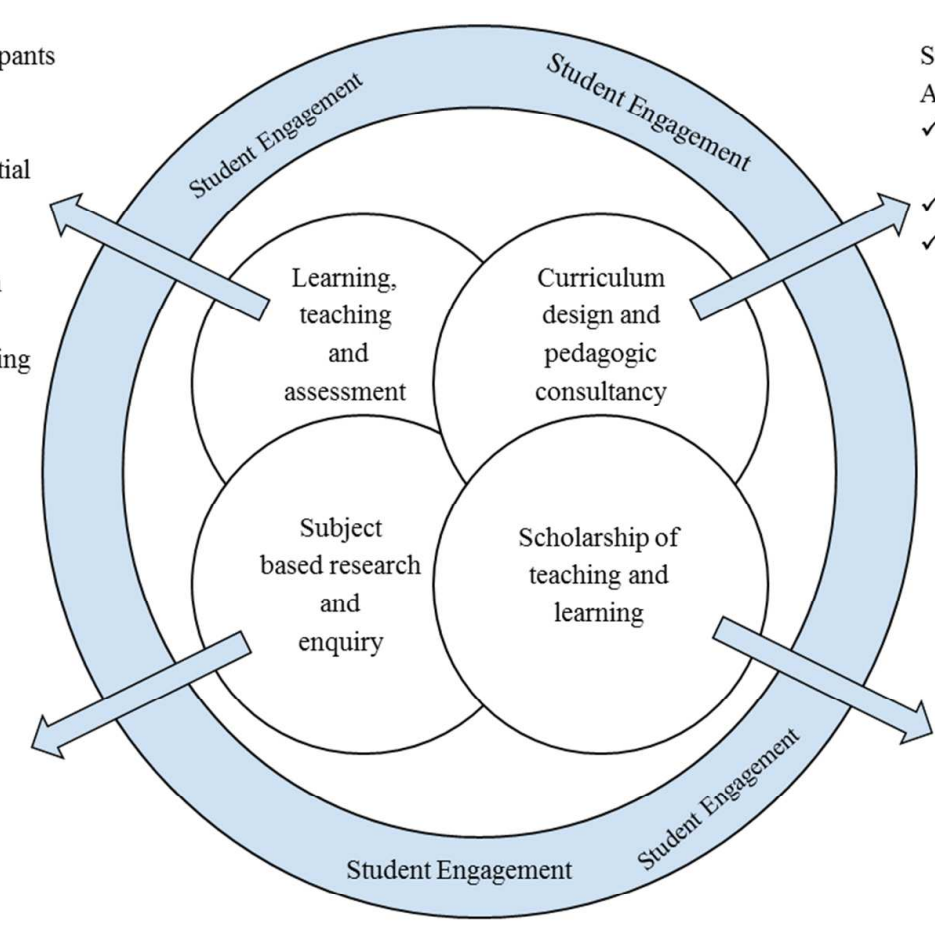

Students as participants in learning and teaching inquiry.

Achieved through:

$\checkmark$ Participation in the game

$\checkmark$ Subjects of research and co-researchers through game enhancement

Figure 3: Students' experiences of playing SSG mapped against the HEA Framework for Engagement through Partnership (Higher Education Academy: 2016)

The intrinsic and extrinsic value identified from the Multifaceted Student Value Model highlights SSG's ability to generate active participation in EfS through the edutainment of game based learning and reflection on action, both of which challenge sustainability thinking within an alternative learning environment. Game playing and game development engage students as producers of knowledge, rather than receivers of information, and subjects of research who contribute to scholarship. Students' roles as co-researchers, game participants and game developers also allow students to evaluate the module content and participate in future curriculum design thus achieving the drivers of engagement incorporated within the HEA framework. 


\section{Implications for Practice}

The results of this research confirm that using SSG as an alternative approach to learning and teaching can positively influence students' engagement EfS. Thus games, if appropriately designed and implemented, can make a difference to learning outcomes and students' value of the learning experience. The fun, interactive and experiential nature of the game appears to generate this value and, even though the student cohort becomes a community of competition, it engenders further engagement. Advocacy for sustainability may result from the cognitive investment, emotional engagement and deep learning achieved.

To make a difference to student engagement it appears that investing in games repays the investment in EfS curriculum design. This is because games are able to address learning expectations of students, develop a focus on learning for insight within EfS and highlight the tensions between profitability and good practice that may engender a sense of personal and business responsibility; a key for sustainable business futures. Games appear to provide an opportunity to provide learning support without simply providing information.

Many businesses claim possession of a range of skills for sustainability to be important when recruiting graduates (Drayson, 2015). This research has identified that SSG contributes to the development of such skills including an understanding of how business decision making conflicts with the most environmentally and socially sustainable actions. SSG also provides an opportunity to engage students in both hard (e.g. financial management and strategy making) and soft business skills (e.g. negotiation, influencing and collaboration) whilst challenging their thinking in a safe learning environment. Participation in the game therefore contributes to employability skills development.

Although this practice-focused study presents the self-reported results of a one-time, small study which does not offer generalised, independently validated responses, the findings may be of interest to educators considering the adoption of game-based learning and those seeking new learning cultures for business sustainability. In order to progress this 


\section{Conclusions}

The research presented here has provided evidence to confirm that the game-based learning and teaching offered by SSG has achieved strong engagement from cognitive investment, emotional commitment and active participation. This has been generated by the entertainment and interactive experiential learning encapsulated in the game. The Multifaceted Student Value Model confirms the value students have placed on the edutainment offered by this approach to learning, a feature supported by the Thematic Analysis of survey responses. The engagement that SSG generates has helped the students recognise they have developed sustainability skills including an understanding of how business decision making conflicts with the most environmentally and socially sustainable actions. SSG has proved able to challenge students' thinking and has provided experience of the softer skills required for a business career such as negotiation, 
collaboration and influencing. These have been practiced in the safe environment of a lecture room. Group interaction (including the community of competition created by students) and learning support experienced during game-play may have contributed the levels of student engagement, bolstering the entertainment and learning the game clearly provides. Further development of the game may encourage an element of collaboration as well as competition.

This research into game-based learning has offered an evidence-based, practical and theoretical example of students' evolving preferences for experiential activities. This is now influencing the author's design and planning of learning activities to support student learning, both in existing modules and potential new programmes for EfS. Additional action research into the effectiveness of this innovative approach to learning and teaching will allow further consolidation of research and scholarship into the professional practice of EfS.

\section{References}

Annetta, L., Minogue, J., Holmes, S.Y., and Cheng, M. (2009), "Investigating the impact of video games on high school students' engagement and learning about genetics", Computers and Education, Vol. 53 No. 1, pp. 74-85.

Armier, D., Shepherd, C., and Skrabut, S. (2016), "Using Game Elements to Increase Student Engagement in Course Assignments". College Teaching 64(2). pp. 64-72.

Barnett, R. (2007), A will to learn: Being a student in an age of uncertainty, McGraw Hill, New York.

Beech, N. and Maclntosh, R., (2012), Managing Change: Enquiry and Action, Cambridge University Press, Cambridge.

Bloom, J. (2010), "Systems Thinking, Pattern Thinking, and Abductive Thinking as the Key Elements of Complex Learning", Denver, Annual Meeting of the American Educational Research Association.

Braun, V. and Clarke, V. (2006), "Using thematic analysis in psychology", Qualitative Research in Psychology, Vol. 3, pp. 77-101.

Burgess, J. (2006), "Blogging to Learn, learning to blog", in: Burns, A. and Jacobs, J. (Eds.) Use of Blogs, Peter Lang, New York, NY, pp. 105-114.

Burns, A. (2005), "Action Research: an evolving paradigm?" Language Teaching, Vol. 38 No. 2, pp. 57-74.

Centre for Systems Solutions, (2017), Green\&Great, available at: https://greenandgreat.games4sustainability.com (accessed 08 October 2017).

Chalkley, B., (2006), Education for Sustainable Development: Continuation Journal of Geography in Higher Education, Vol. 30, No. 2, pp. 235-236. 
Chapman, T. (2012), "Building Young People's Resilience in Hard Times: an evaluation of Telefónica O2 Think Big Programme in the UK”, Middlesbrough, Social Futures Institute, available at: https://www.stchads.ac.uk/wp-content/uploads/2015/09/Building-young-peopleresilience-in-hard-times-O2-Think-Big-Evaluation-Report-May-2012.pdf (accessed 05 October 2017).

Charsky, D. (2010) "From Edutainment to Serious Games: A Change in the Use of Game Characteristics", Games and Culture, Vol. 5 No. 2, pp. 177-198.

Cheong, C., Filippou, J., and Cheong, F. (2014), "Towards the Gamification of Learning: Investigating Student Perceptions of Game Elements", Journal of Information Systems Education, Vol. 2 No. 53, pp. 233.

Cooper, S., Treuille, A., Barbero, J., Leaver-Fay, A., Tuite, K., Khatib, F., Snyder, A., Beenen, M., Salesin, D., Baker, D. and Popović, Z. (2010), "The challenge of designing scientific discovery games", California: Proceedings of the Fifth International Conference on the Foundations of Digital Games; Monterey; 2010. pp. 40-47.

Conole, G., and Alevizou, P. (2010), "A literature review of the use of Web 2.0 tools in higher education", available at: https://www.heacademy.ac.uk/system/files/conole alevizou 2010.pdf (accessed 20 March 2017)

Cross, P. (1987), “Teaching for learning”, AAHE Bulletin, Vol. 39 No. 8, pp. 3-7.

Davis, B., and Sumara, D. (2006), Complexity and education: inquiries into learning, teaching, and research, Routledge, New York.

Dieleman, H. and Huisingh, D. (2006), "Games by which to learn and teach about sustainable development: exploring the relevance of games and experiential learning for sustainability", Journal of Cleaner Production, Vol. 14 No. 9, pp. 837-847.

Drayson, R. (2015), "Employer attitudes towards, and skills for, sustainable development", available at: https://www.heacademy.ac.uk/knowledge-hub/student-attitudes-towards-andskills-sustainable-development-2015 (accessed 10 October 2017).

Ellison, N. and Wu, Y. (2008), "Blogging in the Classroom: A Preliminary Exploration of Student Attitudes and Impact on Comprehension", Journal of Educational Multimedia and Hypermedia, Vol. 17 No. 1, pp. 99-122.

Emblen-Perry, K. (2017), "Promoting Education for Sustainable Development through Game Based Learning", in: Leal Filho W. (eds) Handbook of Sustainability Science and Research. World Sustainability Series, Cham, Springer.

Fabricatore, C. and López, X. (2012), "Sustainability Learning through Gaming: An Exploratory Study", Electronic Journal of E-Learning, Vol. 10 No. 2, pp. 209.

Fazey, D., and Fazey, J. (2001), "The potential for autonomy in learning: Perceptions of competence, motivation and locus of control in first-year undergraduate students", Studies in Higher Education, Vol. 26 No. 3, pp. 245-61.

Figuero, P. and Raufflet, E. (2015), "Sustainability in Higher Education: A systematic review with focus on management education", Journal of Cleaner Production, Vol. 106, pp.22-33.

Frymier, A.B., and Schulman, G.M. (1995), "What's in it for me? Increasing content relevance to enhance students' motivation", Communication Education, Vol. 44, pp. 40-50.

Gee, J.P. (2007), What video games have to teach us about learning and literacy, Palgrave Macmillan, New York.

Hardin, G. (1968), "The Tragedy of the Commons", Science, Vol. 162, No. 3859, pp. 12431248. 
Hays R.T. (2005), "The effectiveness of instructional games: a literature review and discussion", available at: http://handle.dtic.mil/100.2/ADA441935 (accessed 10 October 2017).

HEFCE (2013). "Sustainable Development in Higher Education: consultation on a framework for HEFCE. Higher Education Funding Council for England", available at: http://www.hefce.ac.uk. (accessed 23 March 2017).

Higher Education Academy (2015), "Education for sustainable development (ESD)", available at: https://www.heacademy.ac.uk/workstreams-research/themes/educationsustainable-development (accessed 04 April 2017).

Higher Education Academy (2016), "Higher Education Academy frameWORKS, 04 Essential frameworks for enhancing student success", available at: http//www.heacademy.ac.uk /transform (accessed 04 April 2017).

Iten, N, and Petko, D. (2016), "Learning with serious games: Is fun playing the game a predictor of learning success?" British Journal of Educational Technology, Vol. 47 No. 1.

Kafai, Y. B. (2006), "Playing and making games for learning: Instructionist and constructionist perspectives for game studies", Games and Culture, Vol. 1 No.1, pp. 34-40.

Katsaliaki, K. and Mustafee, N. (2015), "Edutainment for Sustainable Development: A Survey of Games in the Field", Simulation and Gaming, Vol. 46 No. 6, pp. 647.

Kolb, D. A. (2014), Experiential Learning - Experience as the Source of Learning and Development, $2^{\text {nd }}$ edn. Pearson Education Inc, Upper Saddle River, New Jersey.

Krause, K. and Coates, H. (2008), "Students' engagement in first-year university, Assessment and Evaluation in Higher Education", Vol. 33 No. 5, pp. 493-505.

Kuh, G., Kinzie, J. and Buckley, J. (2006), "What matters to student success: A review of the literature", available at: http://nces.ed.gov/IPEDS/research/pdf/Kuh Team Report.pdf (accessed 20 March 2007).

Leach L (2016), "Exploring discipline differences in student engagement in one institution. Higher Education Research and Development", Vol. 35 no. 4, pp. 772-786.

Lizzio, A. and Wilson, K. (2008), "Feedback on assessment: students' perceptions of quality and effectiveness, Assessment and Evaluation in Higher Education, Vol. 33 No. 3, pp. 263275.

McGrath, N. and Bayerlein, L. (2013), "Engaging online students through the gamification of learning materials: The present and the future", in: H. Carter, M. Gosper and J. Hedberg (Eds) Electric Dreams, Macquarie University, Sydney.

Mayer, R. (1996), "Learners as information processors: Legacies and limitations of educational psychology's second metaphor", Educational Psychologist, Vol. 31 No. 3, pp. 151-161.

Meadows, D., Sterman, J. and King, A. (2017) "Fishbanks: A Renewable Resource Management Simulation", available at: https://mitsloan.mit.edu/LearningEdge/simulations/ fishbanks/Pages/fish-banks.aspx (Accessed 10 October 2017).

Miller, J. and Page, S. (2007), Complex Adaptive Systems: An Introduction to Computational Models of Social Life, Princeton University Press, Princeton, New Jersey.

Molthan-Hill, (2014), The business student's guide to sustainable management: principles and practice, Greenleaf Publishing, Sheffield.

Nagle A., Wolf, P., Riener, R. and Novak, D. (2014),"The Use of Player-centered Positive Reinforcement to Schedule In-game Rewards Increases Enjoyment and Performance in a Serious Game", International Journal of Serious Games, Vol. 1 No. 4, pp. 35-47. 
Norridge, J. (2017), "SIM Sweatshop", available at: http://www.simsweatshop.com/game/ (accessed 10 October 2017).

Oblinger, D., and Oblinger, J. (2005), "Educating the Net Generation”, available at: http//www.educause.edu/educatingthenetgen (accessed 01 April 2017)

Pelozi, J. and Shang, J. (2011), "Investing in CSR to Enhance Customer Value", available at: https://corpgov.law.harvard.edu/2011/02/28/investing-in-corporate-social-responsibilityto-enhance-customer-value/ (accessed 10 October 2017).

Plass, J., Homer, B. \& Kinzer, C. (2015) Foundations of Game-Based Learning, Educational Psychologist, Vol. 50 No. 4, pp. 258-283.

Riding, P., Fowell, S. and Levy, P., (1995), "An action research approach to curriculum development", Information Research, Vol. 1 No. 1, pp. 1-7.

Rieckmann, M. (2011), "Future-oriented higher education: Which key competencies should be fostered through university teaching and learning?" Futures, Vol. 44, pp.127-135.

Schell, J. (2008), The Art of Game Design: A Book of Lenses, Morgan Kaufmann Massachusetts.

Schön, D. A. (1987), "Educating the Reflective Practitioner: Towards a New Design for Teaching and Learning in the professions", Jossey-Bass, San Francisco, CA.

Scott, B., Amel, E., Koger, S. and Manning, C. (2016), Psychology for Sustainability (4th edn.) Routledge, Oxford.

Shaffer, D., Halverson, R., Squire, K. and Gee, J. (2005), "Video games and the future of learning", Phi Delta Kappan Vol. 87 No. 2, pp. 105-111.

Stough, T., Ceulemans, K. Lambrechts, W. and Cappuyns, V. (2017) Assessing sustainability in higher education curricula: A critical reflection on validity issues, Journal of Cleaner Production 2017 pp. 1-11.

Stubbs, W. (2011). Addressing the business $\square$ sustainability nexus in postgraduate education International Journal of Sustainability in Higher Education, Vol. 14 No. 1, pp. 25-41.

Tilbury, D. and Wortman, D. (2008), "How is Community Education Contributing to Sustainability in Practice?", Applied Environmental Education and Communication, Vol. 7 No. 3, pp. 83-93.

Traidcraft (2017), “The Orange Trading Game”, available at: http://www.traidcraftschools .co.uk (accessed 09 October 2017).

Tsai, F., Yu K. and Hsaio, H. (2011). "Exploring the Factors Influencing Learning Effectiveness in Digital Game-based Learning". Educational Technology and Society, Vol. 15 , no. 3, pp. $240-250$.

UNESCO (2017). Education for Sustainable Development Goals Learning Objective, available at: http://unesdoc.unesco.org/images/0024/002474/247444e.pdf.

Vanderstraeten, R. (2004), "Education and Society: a plea for a historical approach", Journal of Philosophy of Education, Vol. 38 No. 2, pp. 195-206. 
Wang H, and Sun C (2011), "Game Reward Systems: Gaming Experiences and Social Meanings". Presented at 5th DiGRA Conference: Think Design Play, Hilversum, The Netherlands, 14-17 September 2011.

Wolfe, D. and Byrne E. (1975), "Research on Experiential Learning: Enhancing the Process", Business Games and Experiential Learning in Action, Vol. 2, pp.325-326.

Wrzesien M. and Raya M. (2010), "Learning in serious virtual worlds: evaluation of learning effectiveness and appeal to students in the E-Junior project", Computers and Education, Vol. 55 No. 1, pp. 178-187.

Young,M., Slota, S., Cutter, A., Jalette, G., Mullin, G., Lai, B., Simeoni, Z., Tran, M., and Yukhymenko, M. (2012), "Our Princess Is in Another Castle: A Review of Trends in Serious Gaming for Education", Review of Educational Research Vol. 82, No. 1, pp. 61-89 .

Zepke, N. and Leach, L. (2010), “Improving student engagement: Ten proposals for action”, Active Learning in Higher Education, Vol. 11 No. 3, pp. 167-177.

\begin{abstract}
About the Author
Dr Kay Emblen-Perry is Senior Lecturer in Sustainable Management at the University of Worcester Business School. Her research interests include innovative teaching and learning approaches to business sustainability and behavioural aspects of energy consumption and efficiency in SMEs. In previous roles Kay gained senior project management and purchasing management experience in international automotive companies and has several years' senior environmental and ecology consultancy experience delivering consultancy projects in renewable energy technologies, contaminated land remediation, and ecological assessment for UK organisations.
\end{abstract}

\title{
Disclosure statement
}

No potential conflict of interest was reported by the author. 